\title{
УДК 378.091.3:37.015.31
}

ЛІСОВСБКА Тетяна - кандидат педагогічних наук, дочент, дочент кафедри дошкільної освіти, Миколаївський національний університет імені В.О. Сухомлинського, вул. Нікольська, 24, м. Миколаїв, 54017, Украӥна

ORCID: https://orcid.org/0000-0002-5593-6821

DOI: https://doi.org/10.24919/2413-2039.12/44.21

Бібліографічний опис статті: Лісовська, Т. (2021) Сутність інтерактивних технологій навчання та їх можливості в розвитку творчих здібностей особистості. Людинознавчі студї. Серія «Педагогіка», 12 (44), 135-139, doi: https://doi.org/10.24919/2413-2039.12/44.21

\section{СУТНІСТЬ ІНТЕРАКТИВНИХ ТЕХНОЛОГІЙ НАВЧАННЯ ТА ЇХ МОЖЛИВОСТІ В РОЗВИТКУ ТВОРЧИХ ЗДІБНОСТЕЙ ОСОБИСТОСТІ}

\begin{abstract}
Анотація. У статті автором теоретично обтрунтовано ефективність інтерактивних технологій навчання в процесі розвитку творчих здібностей студентів. Чинна система професійної підготовки досить успішно забезпечує засвоєння майбутніми педагогами знань, умінь $і$ навичок професійної діяльності, а ось розвиток іниих професійних якостей є складним прочесом, шуо вимагає значного підвищення значення професійного виховання, актуалізації процесів самопізнання й самовдосконалення. Вища освіта займає особливе місие в освітній системі, бо вона безпосередньо готує молодь до трудової діяльності, забезпечуючи при цььому різнобічний інтелектуальний розвиток. Вітчизняна система вищої освіти, заснована на стійких традиціях, гнучко реагує на вимоги сучасності і є передовою в галузі впровадження інновачійних технологій. Учені $і$ практики дедалі більше переконуються, що для здійснення сучасних иілей освіти необхідна зміна фундаментальних принцинів навчання, їх філософсько-методологічної парадигми. Однією з таких парадигм може бути визнано інноваційне навчання, щуо включає в себе нові освітні процеси, нові технології.

Ретельне вивчення і аналіз вітчизняної педагогіки дають змогу констатувати, щзо упродовж ХХ століття педагогічна технологія виступала предметом багатьох дискусій та наукових суперечок. Жоден видатний педагог не міг обійти проблему технологізації освітнього процесу. Настільки широкий інтерес до педагогічних технологій викликаний різними мотивами: одні вчені традищійно слідують модним напрямом; інші стурбовані станом освіти і вбачають у технологізації чергову панацеюю від усіх негараздів; треті вважають, щзо технологізація об 'єктивний процес, який підготував етап еволючії освіти для вирішення якісно інших завдань.

Використання інтерактивних технологій у сфері освіти показало, ш⿻ з явилися засоби, спроможні перевести сферу освіти на новий щуабель - щуабель технології. Створення високоефективних технологій навчання дає змогу не тільки студентам підвищувати ефективність засвоєння навчального матеріалу, але $i$ педагогам приділяти більше уваги питанням індивідуального та особистісного зростання студентів.
\end{abstract}

Ключові слова: освітня діяльність, студент, викладач, діалог.

LISOVSKA Tetyana - Candidate of Pedagogical Sciences, Associate Professor, Associate Professor at the Preschool Education Department, Mykolaiv V.O. Sukhomlynsky National University, 24, Nikolskaya str., Mykolaiv, 54017, Ukraine

ORCID: https://orcid.org/0000-0002-5593-6821

DOI: https://doi.org/10.24919/2413-2039.12/44.21

To cite this article: Lisovska, T. (2021) Sutnist interaktyvnykh tekhnolohii navchannia ta yikh mozhlyvosti v rozvytku tvorchykh zdibnostei osobystosti [The essence of interactive learning technologies and their possibilities in the development of personality's creative abilities]. Human Studies. Series of Pedagogy, 12 (44), 135-139, doi: https://doi.org/10.24919/2413-2039.12/44.21

\section{THE ESSENCE OF INTERACTIVE LEARNING TECHNOLOGIES AND THEIR POSSIBILITIES IN THE DEVELOPMENT OF PERSONALITY'S CREATIVE ABILITIES}

Summary. The article theoretically substantiates the effectiveness of interactive learning technologies in the process of developing students'creative abilities. The current system of professional training successfully ensures the acquisition of future teachers' knowledge, skills and abilities 
of professional activity, but the development of other professional qualities is a complex process that requires a significant increase in the importance of professional education, actualization of selfknowledge and self-improvement. High School education occupies a special place in the educational system, as it directly prepares young people for work, while providing diverse intellectual development. The national higher education system is based on stable traditions, flexibly responds to modern requirements and is a leader in the field of innovative technologies. Scientists and practitioners are increasingly convinced that the realization of modern educational goals requires a change in the fundamental principles of learning, their philosophical and methodological paradigm. One of such paradigms can be recognized as innovative learning, which includes new educational processes, new technologies.

Thorough study and analysis of national pedagogy allows us to state that during the XX century pedagogical technology has been the subject of many discussions and scientific debates. There is no an outstanding teacher that could avoid the problem of technologicalization of an educational process. Such a wide interest in pedagogical technologies is caused by various motives: some scientists traditionally follow the fashion trend; others are concerned about the state of education and see technology as another panacea for all illnesses; others believe that technologicalization is an objective process that has prepared the education evolution stage to solve qualitatively different problems.

The use of interactive technologies in the field of education has shown that there are tools that can take the field of education to a new level - the level of technology. The creation of highly effective learning technologies allows not only students to increase the efficiency of learning material, but also teachers to pay more attention to issues of individual and personal growth of students.

Key words: educational activity, student, teacher, dialogue.

Вступ. Кардинальні зміни, що відбуваються в сучасному суспільстві, закономірно зумовлюють необхідність модернізації системи освіти, зокрема професійної освіти. Сучасне суспільство висуває до людини все більш високі вимоги. Життя в епоху науково-технічного прогресу стає різноманітнішим і складнішим. I воно вимагає від людини не шаблонних, звичних дій, а рухливості, гнучкості мислення, швидкої орієнтації й адаптації до нових умов, творчого підходу до вирішення великих і малих проблем.

Таким чином, школа, в тому числі вища, ставить основним своїм завданням створення умов для формування особистості, здатної активно діяти, критично мислити, самостійно здобувати необхідні знання, особистості, спроможної до подальшого саморозвитку, самоосвіти, взаємодії і співробітництва; особистості творчої та активної. Саме ці здібності особистості називаються ключовими в сучасному суспільстві, причому не тільки українському. За дослідженнями зарубіжних соціологів, найбільш «затребуваними» здібностями в сучасному світі є здатність до саморозвитку і співпраці, почуття особистої відповідальності, здатність до критики і прийняття рішення в процесі діалогу. Тому особливу увагу необхідно приділяти розвитку не тільки інтелектуальних здібностей студентів, а й творчих. I перш ніж перейти до технологій розвитку креативних здібностей особистості, зупинимося на самому понятті «творчі здібності».

Аналіз останніх досліджень. Поняття «здібності» $є$ широко вживаними у вітчизняній та західній психолого-педагогічній науковій літературі. Аналіз літератури доводить, що значно більша варіативність визначень здібностей знаходиться в розкритті їх у певній діяльності (Венгер, 1973). 3 позиції психології, «здібності» є індивідуально-психологічними особливостями, які є передумовою успішного виконання певної діяльності і виявляються в процесі оволодіння цією діяльністю (Психологія. Словник, 1990). Визначення здібностей як властивостей або якостей, що допомагають суб'єкту успішно виконувати певну діяльність, на думку О. Коваль, не несе в собі психологічного навантаження, оскільки є надто загальним (Коваль, 2002). Т. Артем'єва, пояснюючи природу здібностей, відштовхується від властивих усім людям загальних здібностей і вважає, що здібності варто розглядати як індивідуальні відмінності, що диференціюють людей. Вона зазначає: «По суті здібність входить до системи властивих певній особистості якостей і є виявом її індивідуальності» (Артем’єва, 1984, с. 46-55). У педагогічному словнику здібності визначено як суб'єктивну умову успішного виконання визначеного типу діяльності: «Здібності не зводяться до знань, умінь та навичок індивіда. Їх проявами $є$ швидкість, глибина, легкість і міцність оволодіння засобами та прийомами діяльності. 
Здібності пов'язані із загальною спрямованістю особистості, ступенем сталості та схильності людини до тієї чи іншої діяльності». Український педагогічний словник визначає здібності як «стійкі індивідуальні психічні властивості людини, які є внутрішньою умовою ії успішної діяльності. Вони виявляються в тому, як людський індивідуум учиться, набуває певні знання, уміння і навички, освоює певні галузі діяльності, включається в творче життя суспільства. У здібностях поєднуються природне і соціальне. Природною основою здібностей є задатки. Сукупність здібностей називають обдарованістю. Визначальними у розвитку здібностей $є$ умови життя і взаємодія з довколишнім середовищем. Здібності людини розвиваються в процесі засвоєння нею суспільного досвіду, виховання і навчання, в процесі трудової діяльності. Здібності поділяються на загальні - такі, що виявляються у всякій діяльності, і спеціальні, характерні для певних їі видів (математичні, технічні, музикальні та ін.). Кожна здібність становить складну синтетичну якість людини, в якій поєднуються окремо психічні властивості (чутливість, спостереження, особливості пам'яті, уяви, мислення). Вищим ступенем розвитку здібностей $є$ талант» (Гончаренко, 1997).

У працях багатьох психологів творчість, творчі здібності особистості часто порівнюються з інтелектом, причому їх взаємозв'язок трактується неоднозначно. Є принаймні три точки зору на співвідношення креативності та інтелекту:

- окремих творчих здібностей не існує. Творчі здібності особистості визначаються іiї когнітивною обдарованістю, мотивацією, цінностями, чутливістю до проблем, незалежністю дій у ситуаціях вибору;

- творчі здібності існують самостійно і практично не залежать від інтелекту;

- творчі здібності адекватні інтелектуальним, тобто чим вища креативність, тим вищий інтелект і навпаки. Окремих творчих процесів без відповідних їм інтелектуальних процесів не існує. Цей погляд, який поділяють багато фахівців у галузі інтелекту, не очевидний для деяких вітчизняних психологів, чиї дослідження показують відмінності в динаміці розвитку креативних та інтелектуальних якостей у студентів.

У сучасному суспільстві дедалі гостріше постає проблема формування творчої особистості. «Особистість, - навчав Аристотель, - це те, що вона сама в собі виховує, виробляє завдяки своїй саморегуляції» (Аристотель, 1983, с. 78). На думку М. Фіцули, творча особистість - це «індивід, який володіє високим рівнем знань, потягом до нового, оригінального, який вміє відкинути звичайне, шаблонне» (Фіцула, 2005). Автор зазначає, що творчій особистості притаманні творчі здібності, які відповідають вимогам творчої діяльності та є умовою ііі успішного виконання. Дослідником розроблена технологія формування творчої особистості, пропонуються принципи організації навчальної діяльності для формування останньої, до яких увійшли: принцип розвитку, який передбачає врахування вікових та індивідуальних особливостей студентів; принцип самодіяльності, метою якого є діяльнісний підхід; принцип самореалізації (Фіцула, 2005). У формуванні здібностей важливе значення відіграє здатність людини «переходити» в процесі діяльності з репродуктивного рівня на творчий. Відповідно до цього «переходу» відбуваються зміни в структурі здібностей суб'єкта. Відомо, що навіть виключно обдаровані люди починали з наслідування, а потім, лише в міру надбання досвіду, проявляли свій творчий потенціал. Таким чином, важливо створити такі передумови, які дають змогу творчості стати нормою в освітній діяльності.

Розвиток творчих здібностей студентів буде ефективним, якщо він буде являти собою цілеспрямований безперервний процес, у процесі якого вирішується низка педагогічних завдань, спрямованих на досягнення кінцевої мети. Для цього необхідна технологізація освітнього процесу, що передбачає відповідну навчальну літературу, дидактичний матеріал, методичні рекомендації щодо його використання, типи навчального діалогу, форми контролю за особистісним розвитком студента в процесі оволодіння знаннями.

У зв'язку з цим нас цікавлять технології навчання, спрямовані на розвиток творчого потенціалу студента, щоб засобами своєї дисципліни, а саме фахових методик, надати кожному індивіду змогу повністю розкрити свої задатки, розвинути творчі здібності та реалізуватись як особистість. 3 усього різноманіття сучасних методів навчання нашу увагу привернули інтерактивні технології навчання (від англ. «Interactive learning»).

Слово «інтерактив» прийшло до нас з англійської мови від слова «interact», де «inten» - взаємний, «асt» - діяти. Інтерактивне навчання - це, перш за все, діалогове навчання, в процесі 
якого здійснюється засвоєння досвіду студентом (стихійне або спеціально організоване) на базі взаємодії з чим-небудь (наприклад, комп'ютером) або ким-небудь (людиною) (Ерімбетова, 2003 , с. 48). Робота з накопиченим досвідом - характерна риса такого навчання. Зауважимо, що йдеться не просто про «підключення» емпіричних спостережень і життєвих вражень учасників як допоміжного матеріалу, «ілюстративного» доповнення. Досвід виступає найважливішим джерелом навчального пізнання. У традиційному навчанні викладач відіграє роль «фільтра», ніби пропускаючи через себе навчальну інформацію. В інтерактивному ж навчанні він виступає як помічник студентів, будучи одним із джерел інформації. Викладач не повідомляє готові знання, а лише спонукає студентів до самостійного пошуку. Іншими словами, цей термін означає здатність взаємодіяти або перебувати в режимі бесіди, діалогу з будь-ким, у результаті чого той, якого навчають самостійно, набуває необхідні знання, вміння та навички, здатність до творчого прийняття рішень у процесі діалогу, до подальшого саморозвитку, самоосвіти, взаємодії та співпраці.

Інтерактивне навчання - це спеціальна форма організації пізнавальної діяльності. Вона має на увазі цілком конкретні і прогнозовані цілі. Одна $з$ таких цілей полягає у створенні комфортних умов навчання, таких, при яких студент відчуває свою успішність, інтелектуальну спроможність, що робить продуктивним сам процес навчання і дає змогу кожному індивіду повністю розкрити себе, свої задатки, розвивати творчі здібності та реалізуватись як особистість.

Мета статті - визначити сутність інтерактивного навчання, яке полягає в організації освітнього процесу, організовано таким чином, що практично всі студенти є залученими в процес пізнання, мають змогу розуміти і рефлексувати з приводу того, що вони знають і думають.

Виклад основного матеріалу. Спільна діяльність студентів у процесі пізнання, засвоєння навчального матеріалу означає, що кожен робить свій особливий індивідуальний внесок, йде обмін знаннями, ідеями, способами діяльності. Причому відбувається це в атмосфері доброзичливості і взаємної підтримки, що дає змогу не тільки отримувати нові знання, а й розвивати саму пізнавальну діяльність.

Найчастіше використовується робота в парах, особливо вона ефективна на початкових етапах навчання. Перевага іiі полягає в тому, що всі учасники мають змогу висловлюватись, обмінюватись ідеями зі своїм напарником, а тільки потім оголосити їх усій групі. Крім того, ніхто з тих, хто навчається, не буде просиджувати час на занятті, як це дуже часто буває, - всі залучені в роботу. Організація інтерактивного навчання передбачає моделювання життєвих ситуацій, використання рольових ігор, спільне вирішення питань на підставі аналізу обставин і ситуації. Прикладами такої роботи є обговорення тексту, взяття інтерв'ю в напарника, аналіз письмової роботи партнера, розробка питань до групи або відповіді на питання викладача і т. ін.

Інтерактив виключає домінування як одного із виступаючих, так і однієї думки проти інших. У процесі діалогового навчання студенти вчаться критично мислити, вирішувати складні проблеми на основі аналізу обставин і відповідної інформації, зважувати альтернативні думки, приймати продумані рішення, брати участь у дискусіях, спілкуватися з іншими людьми. Для цього на заняттях організовується індивідуальна, парна і групова робота, застосовуються дослідні проєкти, рольові ігри, проводиться робота з документами та різними джерелами інформації, використовуються творчі завдання.

Порівняно з традиційним в інтерактивному навчанні змінюються і форми взаємодії з викладачем. Педагог (ведучий) не дає готових знань, але спонукає учасників до самостійного пошуку. Активність викладача поступається місцем активності учасників процесу, оскільки його завдання - створити умови для реалізації ініціативи, активності, творчості студентів.

Іншими словами, інтерактивне навчання - це, насамперед, діалогове навчання, що припускає таку взаємодію викладача і студентів, яка орієнтує особистість на розвиток їі інтелектуальних і творчих здібностей, спрямовує на діяльність, що стимулює «винахідництво» і «відкриття».

Висновки. Підсумовуючи аналіз теоретичних і практичних положень психологів і педагогів із проблеми розвитку творчих здібностей особистості, необхідно зазначити, що звернення сучасної вищої школи до інтерактивних технологій навчання, для яких насамперед характерне стимулювання активного відгуку на творчі (проблемні) ситуації, на наш погляд, здається цілком виправданим. Інтерактивне навчання - це, насамперед, діалогове навчання, в процесі якого студенти взаємодіють, підтримують бесіду, діалог із будь-ким, у результаті чого самостійно 
здобувають необхідні знання, вміння та навички, здатність до творчого прийняття рішень та подальшого саморозвитку і самоосвіти.

\section{ЛІТЕРАТУРА}

1. Аристотель. Сочинения: в 4 т. Москва : 1983. Т. 4. С. 78.

2. Артемьева Т.И. Проблема способностей: личностный аспект. Психологический журнал. 1984. Т. 5. № 3. C. $46-55$.

3. Венгер Л.А. Педагогика способностей. Москва : Знание, 1973.96 с.

4. Гончаренко С. Український педагогічний словник. Київ : Либідь, 1997. 376 с.

5. Еримбетова С. Использование интерактивных (диалоговых) технологий обучения в процессе творческого саморазвития личности учащихся Альма Матер. Вестник высшей школы. 2003. № 11. С. 48.

6. Коваль О.В. Формування музичних здібностей молодших школярів на уроках музики : дис. ... канд. пед. наук : 13.00.02. Ніжинський держ. пед. ун-т ім. Миколи Гоголя. Ніжин, 2002. 251 с.

7. Психология. Словарь / под ред. А.В. Петровского, Г.М. Ярошевского. 2-е изд., испр. и доп. Москва : Политиздат, 1990. 494 с.

8. Фіцула М.М. Педагогіка: Навчальний посібник для студентів вищих педагогічних закладів освіти. 3-те вид., перероб. і доп. Тернопіль : Навчальна книга - Богдан, 2005. 232 с.

\section{REFERENCES}

1. Arystotel. Sochynenyia [Essays] v 4 t. M.: 1983. T. 4. P. 78. [in Russian].

2. Artemeva T.Y. Problema sposobnostei: lychnostnyi aspekt [The problem of abilities: the personal aspect] Psykhol. zhurnal. 1984. T. 5. № 3. PP. 46-55. [in Russian].

3. Venher L.A. Pedahohyka sposobnostei [Ability pedagogy] Moskva : Znanye, 1973. 96 p. [in Russian].

4. Honcharenko S. Ukrainskyi pedahohichnyi slovnyk [Ukrainian pedagogical dictionary]. K. : Lybid, 1997. 376 s. [in Ukrainian].

5. Erymbetova S. Ispolzovanie interaktivnyih (dialogovyih) tehnologiy obucheniya $\mathrm{v}$ protsesse tvorcheskogo samorazvitiya lichnosti uchaschihsya [The use of interactive (dialogue) learning technologies in the process of creative self-development of students] Alma Mater. Vestnyk vysshei shkoly. 2003. № 11. P. 48. [in Russian].

6. Koval O.V. Formuvannia muzychnykh zdibnostei molodshykh shkoliariv na urokakh muzyky [Formation of musical abilities of junior schoolchildren in music lessons]: Dys. ... kand. ped. nauk: 13.00.02. Nizhynskyi derzh. ped. un-t im. Mykoly Hoholia. Nizhyn, 2002. 251 p. [in Ukrainian].

7. Psykholohyia. Slovar [Psychology. Dictionary] / Pod red. A.V. Petrovskoho, H.M. Yaroshevskoho. 2-e yzd., yspr. Y dop. M. : Polytyzdat, 1990. 494 p. [in Russian].

8. Fitsula M.M. Pedahohika: Navchalnyi posibnyk dlia studentiv vyshchykh pedahohichnykh zakladiv osvity [Pedagogy: Textbook for students of higher educational institutions]. 3-tie vyd., pererob. i dop. Ternopil : Navchalna knyha - Bohdan, 2005. 232 p. [in Ukrainian].

Стаття надійшла до редакциї 27.05.2021 